\title{
EL LABERINTO DE LOS ESPEJOS
}

\author{
Túa Blesa \\ Universidad de Zaragoza
}

El espejo, el mundo reflejado, la propia imagen del sujeto proyectada frente a sí mismo, es un elemento de la realidad que, al recrearla virtual, siempre ha imantado la atracción humana. Es ese mostrar lo, sin él, invisible, el enigma, lo que ha llevado a recubrirlo de muy diversos poderes en el folklore universal y las religiones, como muestran los muy diversos motivos especulares recogidos por Stith Thompson (1966). Pero su presencia no se limita al mundo de las supersticiones, sino que se expande al de la ciencia, supuesto que sea otro. En la teoría de la literatura, por ejemplo, es ya una metáfora muy antigua; utilizada desde Platón en su República, llega a la famosa fórmula de Stendhal, que ilustra la relación entre la realidad y el texto, y más modernamente se utiliza también para referirse a un determinado tipo de narración, como, entre otros, muestran los trabajos de Lucien Dällenbach, Le livre et ses miroirs dans l'oetrve de Michel Butor (1972) o Le récit spéculaire. Essai sur la mise en abyme (1977), de expresivos títulos.

Prolongando el interés que siempre ha suscitado en la vida, el espejo es un motivo mitológico y literario que conserva toda su magia, toda su capacidad sémica, y se presenta como símbolo de la vanidad, pero también de la sabiduría; mostrando lo presente invita a la adivinación de lo desconocido, o es instrumento letal, como sucede con el basilisco !. Conocido en todas las épocas, el espejo es más frecuente en algunas de ellas y en determinados autores, y desde el romanticismo aparece en una serie de obras muy significativas de los dos últimos siglos: Jean Paul, Hoffmann, el «William Wilson» de E. A. Poe, El doble de Dostoyevski, El retrato de Dorian Gray de Oscar Wilde, El lobo estepario de Herman Hesse, etc., y también en la poesía de, por ejemplo, Mallarmé o Rilke.

1.- Además de los repertorios simbólicos habituales, puede verse el artículo de Ignacio Malaxecheverría (1989), en el que hay un sugerente recorrido por espejos medievales. 


\section{TÚA BLESA}

El espejo, podría decirse, no es uno, sino múltiple, en cuanto que no aparece vinculado a un único tema, sino que se despliega en varios. Theodore Ziolkowski, en su Imágenes encantadas, ha precisado que las principales categorías de espejos mágicos en literatura son tres:

el espejo catoptromántico en el que uno mira para solicitar información; el espejo de doblaje del que la figura reflejada surge como si se tratara del doble de quien se pone ante él, y el espejo penetrable en el que puede adentrarse quien se mira en él para experimentar sobre el terreno el reflejo de su mundo. Mientras que el espejo catoptromántico no suele pasar del nivel de un motivo menor, las otras dos modalidades se transforman por lo general en imágenes simbólicas: del yo y de un modelo alternativo del mundo. (1980, pp. 143-144).

Pluralidad, pues, de reflejos en la superficie especular y uno de ellos en particular, el espejo que dobla, de interesantes sugerencias en sus destellos, que han captado la atención del psicoanálisis.

Si bien son claramente diferentes los tres tipos de espejos que Ziolkowski señala, todos parecen unificados por un mismo y único valor: en cada uno de ellos el sujeto busca, ya sea el poder mágico, ya a sí mismo, ya la posibilidad de otro mundo. Todo queda, así, en imágenes de búsqueda, pues no en vano allí donde nada hay, como sucede en la superficie del espejo, todo puede ser visto. Jurgis Baltrušaitis ha sintetizado bien este silencio al que el sujeto le proyecta su voz acallada:

Jeroglífico de la verdad, el espejo es igualmente jeroglífico de la falsedad. (1988, p. 281).

La obra poética de Leopoldo María Panero (Madrid, 1948) puede ser vista como una galería de espejos, pues en ella la palabra espejo brilla en casi cincuenta ocasiones, sin tener ahora en cuenta otras expresiones que se conectan con los temas a que aquélla da lugar. Repartidas por casi todos sus libros (por todos, excepto Dióscuros (1982b), que, sin embargo, trae en su título a los gemelos mitológicos, una de las formas de la duplicidad), son más abundantes en los primeros, Así se fundó Carnaby Street (1970) y Teoría (1973), y su número se va reduciendo de manera notable en los últimos ${ }^{2}$. Como se verá en las siguientes páginas, en esta galería se encuentran los tres espejos antes señalados y también otras figuras que permiten volver a hablar de espejos de un modo muy distinto.

El espejo catoptromántico, del que Ziolkowski había observado que se trata de un motivo menor, ofrece en la obra de Panero un único ejemplo, ligado a uno de los textos más conocidos de la literatura infantil, y, diríase, modelo paradigmático del espejo de la adivinación:

\section{BLANCANIFVES SE DESPIDE DF I,OS SIFTE FNANOS}

Prometo escribiros, pañuelos que se pierden en el horizonte, risas que palidecen, rostros que caen sin peso sobre la hierba húmeda, donde las arañas tejen ahora sus azules telas. En la casa del bosque crujen, de noche, las viejas maderas, el viento agita raídos cortinajes, entra sólo la luna a través de las grietas. Los

2.- En 1968 había publicado una colección de cinco poemas titulada Por el camino de Swann, que, íntegra, pasaría a ser la sección "Tarzán traicionado" de $A$ sí... Entre estos poemas figura «Blancanieves se despide de los siete enanos», al que me refiero enseguida en el texto. 


\section{EL LABERINTO DE LOS ESPEJOS}

espejos silenciosos, ahora, qué grotescos, envenenados peines, manzanas, maleficios, qué olor a cerrado, ahora, qué grotescos. Os echaré de menos, nunca os olvidaré. Pañuelos que se pierden en el horizonte. A lo lejos se oyen golpes secos, uno tras otro los árboles se derrumban. Está en venta el jardín de los cerezos.

(Así..., p. 57).

Este breve poema en prosa trae la despedida de Blancanieves, ya salida de su mundo de ensueño poblado de gnomos, que se dirige a un más allá del universo del cuento, en el cual todo está deshaciéndose, desapareciendo, bien sea por alejarse en el espacio, bien por haber sido deteriorado por el tiempo, etc., desde los objetos inertes a la naturaleza viva, incluidos los enanos, cuyo modo de descomposición, por cierto, no deja de resultar sorprendente: sus rostros no se hacen irreconocibles e invisibles por un lógico perderse en el horizonte como sucede con los pañuelos, sino que "caen sin peso sobre la hierba húmeda», desprendidos de sus cabezas, con la levedad del puro vacío.

El poema, por otra parte, es una buena muestra de gran parte de la escritura de Panero y de la de otros poetas coetáneos: todo él está hecho de literatura. No hay que insistir en la presencia del relato de Blancanieves, que lo toma por entero, pero síllamar la atención sobre la desoladora frase final, en la que se encierra el título de Chejov El jardín de los cerezos, donde un mundo está en trance de descomposición ${ }^{3}$. El texto que se le ofrece al lector viene a ser una página desconocida del relato de Blancanieves, un último capítulo, un epílogo, con el quc Panero prolonga el cuento. Pero en esta página Blancanieves no es tan sólo la heroína del cuento, sino una máscara para el yo poético, en cuyo discurso resuena el adiós de éste al mundo de la infancia, donde, como en el relato, las hadas y la fantasía eran posibles, el habla gratuita, el juego sin reglas, el tiempo sin medida ni conciencia, la vida sin muerte. De aquel paraíso - el cuento, la niñez-, al final «uno tras otro los árboles se derrumban».

En cuanto al espejo, su presencia se da, en tanto que es motivo del cuento infantil, en la enumeración de éstos («espejos [...], envenenados peines, manzanas, maleficios»). En el cuento, el espejo habla, contesta a la madrastra, pero esa capacidad mágica se ha disuelto en este epílogo, en el que Panero los nombra "silenciosos», pérdida de un poder, que no es sino la variante correspondiente del valor general de destrucción, de negación, que impregna al texto. Alejándose de la ruina, Blancanieves dirá «Prometo escribiros» y la voz enmascarada, la de Leopoldo María Panero, escribe un poema de despedida a la ya fábula de la inocencia y la vida. Ya ante los primeros textos de Panero, incluido «Blancanieves...», Pedro Gimferrer había hecho referencia a los mismos como "maltrechos despojos fulgurantes de una infancia derruida» (1968, p. 22).

Siendo que lo característico de los espejos es devolver la imagen que se les enfrenta, en ocasiones su superficie no dibuja el reflejo, sino que es puerta que se abre y, como dice Ziolkowski, «el ser humano entra en el espejo, que se vuelve el símbolo de una realidad diferente, de un orden completamente distinto» (1980, p. 185). Esta posibilidad de vivencia de un mundo desconocido, esta invitación, por tanto, a la negación de la realidad, aparece en varios textos de Panero, por cierto que, como en el caso anterior,

3.- Que El jardín fue lectura «familiar» de los Panero lo revelan las palabras de su hermano Juan Luis, quien a la incitación de Fernando Valls «Otro autor que te interesa mucho es Chejov», dice: «Muchísimo. Me interesa no el autor de los cuentos humorísticos, que sólo me entretienen, sino el Chejov profético que está viendo el fin de un mundo, como en El jardín de los c'erezos, y lo pone tal cual, con un gran contenido poético nos muestra una realidad trascendida» (1988, p. 11). 


\section{TÚA BLESA}

también entre los primeros de su escritura. En el poema "20.000 leguas de viaje submarino», de $A$ sí..., se lee:

$$
\begin{gathered}
\text { dejadme entonces besar este astro apagado traspasar el espejo } \\
\text { y llegar así adonde ni siquiera el suspiro es posible }
\end{gathered}
$$

$$
\text { (p. 70). }
$$

Bajo una nueva referencia a la literatura fantástica en el título, este verso expresa el deseo de "traspasar el espejo», metáfora de acceder a otro mundo, de vivir otra vida. Esta huida de la realidad, esta evasión, se convierte al final en algo que parece una súplica de la muerte, pues termina:

y cerrar por fin los ojos cuando la mariposa próxima a caer sobre la tierra sorda quiere en vano volver sus alas hacia lo verde que ahora la desconoce.

$$
\text { (p. 70). }
$$

Una vez visto ese mundo al que se ruega acceder, no queda otra aspiración que la muerte, siendo la vida ya invivible.

Por otra parte, el poema no parece ajeno a la sensibilidad que dibuja alguna droga. Habría que subrayar en el título la palabra viaje o algo de lo que se dice en los primeros versos:

Como un hilo o aguja que casi no se siente como un débil cristal herido por el fuego como un lago en que ahora es dulce sumergirse oh esta paz que de pronto cruza mis dientes este abrazo de las profundidades

(p. 69).

No sería un caso peculiar en el contexto de los restantes poemas de $A$ sí..., como el título "La canción de amor del traficante de marihuana» (p. 71) - de nuevo con su intertextualidad entretejida-y varias otras menciones (vid. pp. 15, 17, 21, 22, 45). Y no pueden olvidarse las vivencias del propio poeta en aquellos años. Poco después de que escribiera este libro, explicaba en una entrevista:

la poesía surrealista es muy fácil de hacer, sin necesidad de alcohol, pero irreflexivamente, como hace Gimferrer o gente así, o con drogas, como lo estaba haciendo yo. Al fin y al cabo, mi libro Así se fundó Carnaby Street corresponde a ese tipo de línea (Campbell, 1971, p. 18).

Tal vía de inspiración, tal experiencia de vida, llevaría al poeta a estrellarse con los poderes policial y psiquiátrico, al menos.

Ziolkowski, por su parte, se pregunta si será casual que este espejo que da acceso a otro universo, el espejo del doble y otras imágenes que él estudia "se manifestaran en víspera de la era de las drogas, que vienen a ampliar la perspectiva de la conciencia, y de la exploración espacial» (1980, p. 212). Hay que decir que en los años en que Panero escribe estos poemas se produce una expansión extraordinaria en el consumo de drogas, distintas del alcohol, en los países llamados occidentales - y, desde luego, en España-y que muchos de los escritores ligados a drogas forman parte de las lecturas preferidas de Panero.

El título clave en la tradición del espejo como entrada a otro mundo, otra realidad, 


\section{EL LABERINTO DE LOS ESPEJOS}

es, por supuesto, Through the looking-glass and what Alice found there, de Lewis Carroll, cuya obra maravillosa está muy presente en el quehacer literario de Panero. Además de ser traductor - y prologuista - de una serie de escritos lógicos y matemáticos del reverendo Charles Dodgson bajo el título Matemática demente (1979a) y del poema The hunting of the Snark (1982a), ejemplo éste del ejercicio que Panero denomina «perversión», pueden citarse varios otros ejemplos de la lectura de Carroll en su obra poética. Entre ellos, estos versos del primero de los textos que componen «El canto del llanero solitario», de Teoria:

Verf barrabum qué espuma

reencarnación

en lo dorado de mi pensamiento

Alicia

qué hago

Verf barrabum

ves la espuma inmóvil en mi boca?

aquí sólo a caballo Verf barrabum qué

hagoaliciaenelespejoven

aquí a mi palacio de cristal

(p. 16).

Junto a la reencarnación, la invitación de Alicia desde el espejo o ya desde el otro lado en un verso, cuya peculiar cscritura -no hay ningún otro caso scmejante en todo cl largo poema - lo subraya en el discurso delirante en el que se encadenan las intertextualidades y las visiones de otra realidad. Reencarnación, esto es, ser otro o en otro mundo.

Este espejo carrolliano, que llama hacia sí, está unido hasta tal punto a su valor de frontera entre la realidad vivida y la fantasía, que puede desvincularse del resto de los elementos del relato al que pertenece e integrarse en otro conjunto textual, como sucede en el poema «Unas palabras para Peter Pan», de Así..., en el cual la puesta en escena es muy similar a la de «Blancanieves...», antes comentado 4 . Como en este poema, ahora también el sueño ha terminado, según expresan diversas formas de destrucción, de negación de alguna clase de existencia («el barco pirata naufraga, Campanilla cae al suelo sin un grito, los Niños Extraviados vuelven el rostro a sus esposas o toman sus carteras de piel bajo el brazo, Billy el Tatuado saluda cortésmente», p. 11). Y tras esta extinción de los personajes del cuento de James Matthew Barrie - que a algunos alcanza parcial, aunque sustancialmente-, no queda sino la que es declaración definitiva:

Peter Pan no existe. [...] Peter Pan no es más que un nombre, un nombre más para pronunciar a solas, con voz queda, en la habitación a oscuras. (p. 12)

Quizá ya sobre el jardín de los cerezos han edificado, y el poema equipara noexistencia a no-ser-más-que-un-nombre, lo que sugiere una interpretación metaliteraria, según la cual el poema, sólo una cadena de nombres, de palabras, es nada. Pero lo que me importa señalar en este poema es que, siendo que en Peter Pan no hay ningún espejo que dé acceso a la Isla-Que-No-Existe, aparece incorporado al poema:

Usted lleva razón, señor Darling, Peter Pan no existe, pero sí Wendy, Jane, Margaret y los Niños Extraviados. No hay nada detrás del espejo, tranquilícese, señor Darling. (p. 12)

No hay confusión o descuido, sino contaminación de un relato en otro toda vez que

4.- Es, por otro lado, uno de los cinco poemas de Por el camino de Swann. 


\section{TÚA BLESA}

el mundo al que Peter Pan da acceso es también el del otro lado del espejo, puro símbolo. Hay que negar la confusión o el descuido por la intensa relación de la obra de Leopoldo María Panero con el cuento de Barrie, cuya primera muestra es el texto citado. Recogeré ahora otro muy próximo, la «Poética» incluida en la antología de José María Castellet Nueve novísimos poetas españoles (1970), en la cual un parlamento de Garfio explica:

Todas mis palabras son la misma que se inclina hacia muchos lados, la palabra FIN, la palabra que es el silencio. [...] Fs la tragedia convertida en absoluto y por consiguiente desaparecida. Es la muerte que desaparece. [...] Se trata siempre del fin de la tragedia. (pp. 239-240).

No resulta mala la apreciación crítica de Garfio, como los poemas citados hasta ahora indican, «la palabra FIN» podría ser título o resumen de cualquiera de ellos.

Otras conexiones de la obra de Panero con el citado cuento son: «Hortus conclusus», un "Guión cinematrográfico basado en Peter Pan de James Matthew Barrie y en The wicked voice de Vernon Leen, recogido en el libro En lugar del hijo (1976, pp. 157-174); la traducción del cuento con un breve prólogo (1987b), donde se reproduce como apéndice el referido guión, reescrito (pp. 363-379) 5 ; y un poema del último de sus libros, Contra España y otros poemas no de amor (1990), el titulado «Peter Punk», al que pertenecen estos versos:

Peter Punk es el amor y Campanilla su princesa

Garfio busca en vano el secreto de su mano

y Campanilla llora al pie del Árbol Extraviado

adónde las sirenas y adónde los enanos

Peter Punk intenta en vano su amor explicar

en una playa desierta Campanilla lo dejó.

Aunque metamorfoseado, el personaje que hacía vida de las ilusiones vuelve a rodearse de un paisaje final, un pasaje en el que las palabras muestran su incapacidad ${ }^{6}$.

Un último texto mostrará qué hay o qué se busca al otro lado del espejo en la poesía de Panero. Véase el comienzo del poema [V] de Así...:

Noemí. El mundo del espejo. La libertad. El otro Sol. El Oro.

Pero lo que empieza siendo una enumeración de elementos marcados positivamente se convierte en algo muy distinto en las últimas líneas:

Destrucción. La emboscada, los disparos, la sangre. Los cuervos heridos bañados por la luz de los relámpagos.

La noche sin fin.

5.- La «Poética» de Nueve novisimos se presenta como perteneciente a «Hortus conclusus», pero en las dos versiones de éste a las que me refiero en el texto no se incluye tal fragmento.

6.- Evidentemente, este Peter Punk supone un cruce entre Peter Pan y Peter Pank, el personaje de los cómics de Max publicados, entre otras revistas, en El vibora. El poema, así, muestra la pervivencia en la obra de Panero de los personajes provenientes de los medios de comunicación de masas, cuya presencia señaló Castellet como uno de los rasgos de cierto estilo novísimo (1970, p. 43). 


\section{EL LABERINTO DE LOS ESPEJOS}

Ya había advertido Ziolkowski que se trataba de una imagen «esencialmente multivalente» y que «el espejo penetrable puede simbolizar el reino de la muerte (el Orfeo, de Cocteau), el mito intemporal (la Lilith, de MacDonald) o una realidad invertida ( $A$ través del espejo, de Lewis Carroll)» (1980, p. 207). Los ejemplos de Panero considerados antes, «20.000 leguas...» y «El canto...», serían muestra de este último valor carrolliano - y, si de la realidad a la que dan paso no es fácil decir si es invertida, sí es al menos otra 7 - y el último de los poemas citados se abriría al espacio de la muerte, la palabra FIN, como muchos otros de sus textos. Aspiración de otro mundo, de ser otro - soñado imposible- del que se es.

La otra categoría de espejo de las que habla Ziolkowski es la que se vincula a su función elemental de reflejar, la que da lugar al tema del doble, de la que en la poesía de Leopoldo María Panero se encuentran diversos ejemplos y, como sucedía en los casos anteriores, también los hay ligados a la tradición. Así, el título de uno de sus libros es Narciso en el acorde último de las flautas, donde se recoge el mito clásico en el que la visión de la propia imagen es el umbral de la muerte. Si todo esto lo hace presente el simple nombre del joven protagonista de una metamorfosis floral, queda aquí subrayado por el instante en el que se ha fijado el título: «el acorde último de las flautas» antes de que la música dé en el silencio infinito, no aludida la insatisfacción amorosa primera ni el éxtasis de la contemplación del propio rostro ${ }^{8}$. También de raíz clásica es el título de Dióscuros, ya citado, al que los gemelos Cástor y Pólux dan nombre, pero que no aparecen en ninguno de los poemas del libro, de manera que es la pura dualidad lo que se destaca.

Un texto muy importante entre los que desarrollan el tema del doble es el titulado "Ann Donne: undone», de Así..., cuyo título recoge un juego de John Donne y es, por otra parte, la duplicación (prácticamente) de una secuencia fónica. Los primeros versos presentan ya uno de los personajes más típicos del doble:

Tantas veces tus pasos he creído escuchar

William Wilson, tus pasos, detrás de mí, a lo largo de los interminables Corredores

Desnudos como el Invierno

Como el invierno propicios a fantasmas y a Ecos,

$[\ldots]$

Su anticipación, su Espejismo

Como la sombra de los Verdaderos Espejos

A que éstos conducen

(p. 74).

En el conjunto del poema, la palabra "espejo» se lee hasta cinco veces, tantas como «sombra», «espejismo» y «eco» dos cada una, «huella» una (la mayor parte de ellas con

7.- Como dice Umberto Eco, «el espejo refleja la derecha exactamente donde está la derecha y la izquierda donde está la izquierda. Es el observador [...] quien por ensimismamiento se imagina ser el hombre que está dentro del espejo y, al contemplarse, advierte que lleva, pongamos, el reloj en la muñeca derecha» (1988, p. 15).

8.- El mito da nombre al narcisismo, concepto fundamental del psicoanálisis. Louise Vinge, en The Narcissus Theme (1967), —además de estudiar el uso literario del mito en la literatura europeapasa una rápida revista a algunos tratamientos psicoanalíticos. A los estudios allí citados hay que agregar, al menos, varios de los trabajos de Jacques Lacan, como sus seminarios «Sobre el narcisismo» o «Los dos narcisismos» (1990, pp. 167-181 y 183-196). 


\section{TÚA BLESA}

mayúscula inicial de altura simbólica) y seis ocasiones el nombre de William Wilson ${ }^{9}$. Se trata, por supuesto, del héroe del relato que lleva su nombre de E. A. Poe, en el cual este personaje se ve perseguido desde el colegio por otro William Wilson, compañero de estudios, nacido en la misma fecha que él, de su misma estatura y sorprendente parecido en las facciones y el aspecto físico y cuya voz incluso resultaba ser el eco de la suya propia. Tras diversos encuentros en los que el doble desbarata los planes del protagonista, éste le reta a un duelo a espada y, tras herirle, algo extraño sucede — «Donde antes no había nada, alzábase ahora un gran espejo (o por lo menos me pareció así en mi confusión)»-, por lo que cree ver, dice, que «mi propia imagen, pero cubierta de sangre y pálido el rostro, vino a mi encuentro tambaleándose» (1972, p. 73). Disipada la equivocación, reconoce en la imagen del herido al doble, quien le dice:

Has vencido, y me entrego. Pero también tú estás muerto desde ahora... muerto para el mundo, para el cielo y para la esperanza. ¡En mí existías... y al matarme, ve en esta imagen, que es la tuya, cómo te has asesinado a ti mismo! (ibid.)

Como sucede en el caso de Narciso, también William Wilson encuentra la muerte a manos de su propia imagen, de su doble.

En este poema, pues, el doble no es un sosias, no se llama «Leopoldo María Panero», sino William Wilson, caso particular del tema del doble erigido en símbolo del mismo. Como en el relato de Poe, W. W. resulta amenazante, perseguidor («he creído escuchar/[...] tus pasos, detrás de mí»), en un escenario de tonos góticos («interminables Corredores», «el Salón de los Espejos»), sin embargo, al final del poema se lee:

No es verdad William Wilson,

WILLIAM WILSON NO EXISTE

$O$ al menos no es Aquel que nos salvará de la Ceniza

Pues es él mismo quien nos conduce a la Ceniza:

Las Cadenas del Demonio se deshacen con inocente crueldad en las manos de los Sedientos.

$$
\text { (p. 77). }
$$

Los dos primeros versos de este fragmento son un restablecimiento del sujeto, niegan el doble y, en él, la muerte, pero los tres restantes nos traen la negación de un William Wilson salvador y la confirmación de uno terrible, ues él mismo quien nos conduce a la Ceniza", mientras se deshace la cadena - símbolo de unión entre los extremos inicial y final-del tiempo hacia la muerte, es el doble exterminador.

Pero eso no es todo, el poema tiene también un sentido metaliterario, según palabras del propio poeta:

Empieza con la destrucción de la mujer, pues el título proviene de un poema de John Donne que escribió a la muerte de su mujer, aprovechando la similitud fonética de undone y Ann Donne, que significa la destrucción de la mujer. En mi poema, William Wilson también simboliza lo mismo: es el doble que tratas de buscar pero que no existe. Es la mujer y la destrucción del amor como imposibilidades absolutas. Como dice al final el poema: William Wilson no existe, o en

9.- En cuanto a las equivalencias, evidentes por lo demás, es curioso el dato que recoge Otto Rank en su estudio sobre el doble de que «les Abipons ne possédent que le seul mot loakal pour ombre. âme, image, écho» $(1965$, p. 61). 


\section{EL LABERINTO DE LOS ESPEJOS}

todo caso es aquel que nos conduce a las cenizas. Y la comparación entre la mujer y la poesía es el salón de los espejos a favor de esta última. (Campbell, 1971, p. 20).

W. Wilson es, pues, un ideal, inexistente, pero buscado. En el caso del escritor, el ideal no es otro que el texto perfecto, o el texto sin más, que, en cuanto imposible, conduce a las cenizas del vacío.

El tema del doble, en sus manifestaciones folklóricas y literarias, ha atraído la atención de los psicoanalistas. Un estudio fundamental es el que le dedicó Otto Rank, para quien el doble, «en dernière analyse, n'est pas autre chose que le problème de la mort dont le moi se sent toute la vie menacé» $\left(1965\right.$, p. 14) ${ }^{10}$. En efecto, según Rank, se trataría de un proceso en el que «au début le Double-Moi avait précisément pour fonction de nier la mort» (p. 68). Este doble yo sería una creación -consecuencia de la conciencia de la muerte- del narcisismo que no puede tolerar esa realidad, y es este narcisismo,

se sentant particulièrement menacé par la destruction inévitable du Moi, qui a créé comme toute première représentation de l'âme une image aussi exacte que possible du Moi corporel, c'est-à-dire un véritable Double pour donner ainsi un démenti à la mort par le dedoublement du Moi sous forme d'ombre ou de reflet. (p. 112).

Pero, como ya he advertido, la explicación de Rank conlleva todo un proceso, del que lo anterior es el estadio inaugural y que dará en una valoración muy diferente, pues

Avec le développement de l'intelligence chez l'homme et la notion consécutive de culpabilité, le Double qui, à l'origine, était un substitut concret du Moi, devient maintenant un diable ou un contraire du Moi, qui détruit le Moi au lieu de le remplacer. (p. 115).

De este modo, destruyendo el yo, el sujeto, se comporta el doble en el mito de Narciso, en «William Wilson» de Poe y también en el poema de Panero.

En su ensayo sobre lo siniestro (das Umheimliche), Sigmund Freud recoge la explicación de Rank, de la que parte la suya propia, según la cual, el doble puede adquirir otros contenidos. En la evolución del yo se desarrolla una instancia que sirve a la autoobservación y a la autocrítica, "que cumple la función de censura psíquica», escribe Freud, quien añade:

La existencia de semejante instancia susceptible de tratar al resto del yo como si fuera un objeto, o sea la posibilidad de que el hombre sea capaz de autoobservación, permite que la vieja representación del doble adquiera un nuevo contenido y que se le atribuya una serie de elementos: en primer lugar, todo aquello que la autocrítica considera perteneciente al superado narcisismo de los tiempos primitivos.

Pero no sólo este contenido ofensivo para la crítica yoica puede ser incorporado al doble, sino también todas las posibilidades de nuestra existencia que no han hallado realización y que la imaginación no se resigna a abandonar, todas las aspiraciones del yo que no pudieron cumplirse a causa de adversas circunstancias exteriores, así como todas las acciones volitivas coartadas que han producido la ilusión del libre albedrío. (1979, p. 24).

10.- Siguiendo a Rank, Isabel Paraíso lleva a cabo un fino análisis de El otro de Unamuno (1987). 


\section{TÚA BLESA}

Por otra parte, el doble es, para Freud, una imagen de lo siniestro, sobre lo que más adelante volveré.

Frente a la explicación de Rank, que pretende la generalidad, el planteamiento de Freud abre las interpretaciones particulares del doble en cada una de sus manifestaciones $y$, por otra parte, la identificación del doble con las varias instancias - yo, superyó, ello- que el psicoanálisis figura (vid. Rogers 1970 para un análisis detallado de ello).

Volviendo al simbolismo general, también Gilbert Durand atribuye un sentido de muerte al espejo y al reflejo de la imagen. Siguiendo a Bachelard, el espejo es equiparado por Durand al agua, pues el agua "fue el primer espejo durmiente y sombrío» (1981, p. 89) y en el fluir del agua se revela el devenir, en él se dibuja uno de los rostros imaginarios del tiempo.

Otros textos de Leopoldo María Panero ilustran esta vinculación entre el doble y la muerte. Así, por ejemplo, en «Destruktion ficticia»:

La sin sombra, la de los muchos nombres, y ninguno, [...] al otro lado, no ya el cuervo sobre el busto de Palas, es decir, un doble fondo en ausencia de un fondo, sino un jardín a la vez público y privado, único, y otra redención (que no fuera ésta) de nuestra sociedad, de nuestra unicidad, por intermedio de la duplicidad. (Teoría, p. 10).

En este poema, que establece de nuevo una llamativa intertextualidad con el poema de E. A. Poe «The raven» (en el que el cuervo "Perched upon a bust of Pallas»), la unicidad no es sino un estado negativo, por lo que se espera, se desea, la redención «por intermedio de la duplicidad», todo ello tras la presencia de la muerte («La sin sombra, la de los muchos nombres, y ninguno»). Por lo demás, esta redención ha de ponerse junto a los pasos al otro lado del espejo de otros de los poemas de Panero.

Otra exaltación de la duplicidad puede leerse en el poema [II] de Dióscuros:

Me dijo un griego en Creta que cuando alguien se quita

la vida por su propia mano

Dyonisos el oscuro canta, en su cueva canta

y el eco de Cibeles da sentido a su canto

porque ser dos es todo, como fue para Atthis.

(p. 10).

La muerte se enlaza al canto de Dionisos doblado en el eco de Cibeles y, en el último verso, la sentencia es concluyente: «ser dos es todo». Está además la mención de Atis, cuya castración no es sino una muerte simbólica y en el que se establece la dualidad, pues, siendo hombre, está castrado (vida/muerte).

Ahora bien, el espejo puede traer una imagen que no sea la del sujeto, en cuyo caso el doble especular abre un interrogante sobre la identidad, que el sujeto no reconoce en el reflejo. Margaret Stoljar ha señalado que «the most radical uncertainty brought to the surface of consciousness by the power of active mirroring concerns the sense of personal identity itself and its possible loss» (1990, p. 369), lo cual - como bien dice la autora«is a theme pursued often in symbolist and post-symbolist writing, both in poetry and in prose narrative» (ibid.). En cuanto que heredera, entre otras, de esta tradición, la poesía de Panero también recoge tal indagación, pero no de una manera ocasional, sino haciendo de ella uno de sus temas más característicos. Esta búsqueda de la identidad habla, por 


\section{EL LABERINTO DE LOS ESPEJOS}

supuesto, de una pérdida: no ser yo es ser nadie o ser otro. Estos versos de un poema de Teoria ofrecen una muestra:

Nefasto arregla su jardín

bajo la luz de plomo

por un viento inhumano barridos los harapos

y en el espejo mi rostro no está.

$$
\text { (p. 66). }
$$

Recoge este poema el motivo folklórico $-\mathrm{y}$ literario - de la falta de reflejo de seres espectrales como los vampiros o los fantasmas, pero en otros textos el conflicto de la identidad lo expresa el desconocimiento de sí, que, en cuanto modalidad de una noexistencia, aparece en los poemas frecuentemente enlazado con la mención de la muerte. Así, en estos versos de Last river together (1980a):

Si no es ahora ¿cuándo moriré?

Si no es ahora que me he perdido en medio

del camino de mi vida, y voy

preguntando a los hombres quién soy, y

para qué mi nombre, si no es ahora

¿cuándo moriré?

$[\ldots]$

si no es ahora que está como caído

mi nombre al pie de mí.

$$
\text { (p. 22). }
$$

Incorporando de nuevo una cita literaria, Dante, el poema termina con la pérdida del nombre «caído».

O también, en «Trovador fui, no sé quién soy» (de El último hombre, 1984), de título suficientemente explícito, cuyos últimos versos dicen:

Tuve la voz, trovador fui

hoy ya cantar no sé

trovador, no sé hoy quién soy

y en la noche oigo a un fantasma

a los muertos recitar mis versos.

(p. 28).

Ese yo que tuvo el canto, que fue trovador, pero que en el momento presente ya no lo es, ha perdido con la voz poética su propia identidad y aún ha de oír a un ser fantasmal, imagen del vacío de sí mismo sin nombre, recitar unos versos a un público, que, a su vez, carece no ya de nombre, sino de la vida misma, o uno y otra lo mismo.

La conjunción de la carencia de identidad y muerte se repite de modo muy similas en este texto de Poemas del manicomio de Mondragón (1987a):

Debajo de mí

yace un hombre

y el semen

sobre el cementerio

y un pelícano disecado

creado nunca ni antes

Caído el rostro 


\section{TÚA BLESA}

otra cara en el espejo

un pez sin ojos

Sangre candente en el espejo

sangre candente

en èl espejo

un pez que come días pre-

sentes sin rostro.

(p. 49).

Ahora bien, en este poema ( $C$ Caído el rostro/otra cara en el espejo»), ya no hay ausencia de reflejo, carencia de nombre, sino que el espejo, haciendo uso de sus virtudes mágicas, devuelve una imagen que no se recococe como la propia, sino que es la de otro. Como en el texto siguiente:

\section{ESCRITO SOBRE UN VERSO DE CAVAFIS}

No me engaña el espejo:

esa mujer soy yo,

la que el espejo prolonga

[...]

y baila, baila desnuda

ante la copa del espejo

ante la sangre que derraman los ojos

y que es su vestido, su ropa

que no existe, y se deshace

como las hojas en el otoño

del espejo.

(El que no ve, 1980b, p. 16) ${ }^{11}$.

En los poemas anteriores, el otro no tiene nombre, pero en la obra de Panero pueden señalarse varios textos en los que, monólogos dramáticos, el yo adopta las voces e identidades de otro, como en este poema de El último hombre:

\section{REQUIEM}

Yo soy un hombre muerto al que llaman Pertur.

En la cena de los hombres quién sabe si mi nombre

algo aún será: ceniza en la mesa

$o$ aditamento para el vino.

$$
\text { (p. 13). }
$$

Aquí la máscara es el dirigente de ETA desaparecido en no explicadas circunstancias y sirve una vez más para presentar a un yo ya muerto, con nuevas preguntas sobre el nombre. En otro poema («La flor de la tortura», del mismo libro que el anterior), el personaje que declama es Tupac-Amaru en el delirio de la tortura:

Busco aún mis ojos en la Mano

en la Mano y en el suelo,

y recuerdo que fui hombre,

antes

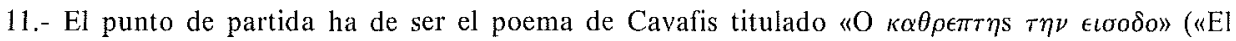
espejo del recibidor»), aunque el espejo es el único vínculo entre ambos textos. 


\section{EL LABERINTO DE LOS ESPEJOS}

de que el metal hiciera arder mi cuerpo

entero como una bombilla, como un bombilla quebrada por la Mano

del hombre sin cabeza.

$$
\text { (p. 14). }
$$

Más insólita puede parecer la declaración «Yo soy un lamed wufnik/sin mí el universo es nada» («Lamed Wufnik», de Poemas del manicomio de Mondragón, p. 23), identidad misteriosa tomada, una vez más, de la literatura, como el propio Panero indica en una nota, en la que remite a "Los Lamed Wufniks", de Jorge Luis Borges 12 .

Considérese, por fin, el poema "Vaso", de El que no ve:

Hablamos para nada, con palabras que caen
y son viejas ya hoy, en la boca que sabe
que no hay nada en los ojos sino algo que cae
flores que se deshacen y pudren en la tumba
[...
y de pronto, en el bar, tan solos, sí tan solos,
me asomo al pozo y veo, en la copa un rostro
grotesco de algún monstruo
que ni morir ya quiere, que es una cosa sólo
que se mira y no ve, como un hombre perdido
para siempre al fondo de los hombres
extranjero en el mundo, un extraño en su cuerpo
una interrogación tan sólo que se mira sin duda
con certeza, perdida al fondo de ese vaso.

(p. 29).

Tras unos primeros versos que hacen presente la muerte, aparece la superficie especular, que en este caso es el alcohol en el cristal, y la imagen que devuelve es, en primer lugar, «un rostro/grotesco de algún monstruo»y, finalmente, "una interrogación», una búsqueda que no alcanza a obtener ninguna respuesta que no sea el silencio y la nada.

Como ha escrito Gilbert Durand, «mirarse es ya un poco ofelizarse y participar en la vida de las sombras» (1981, p. 94) y, así, este ver otras imágenes distintas de la propia en el espejo, este no saber quién se es, quizá como única posibilidad de ser, no son sino formas de muerte, visiones de la vida de las sombras.

Con esta pérdida de la identidad e inquisición de identificaciones hay que poner en relación dos conjuntos poéticos de Panero: «El canto del llanero solitario» (Teoria) y «De cómo Ezra Pound pasó a formar parte de los muertos, partiendo de mi vida» (El último hombre). Uno y otro son ejercicios poéticos, en los que el yo adopta multitud de rasgos de la escritura de Ezra Pound en The Cantos (el primero, incluso, recoge la palabra «canto» en su título). Ambos conjuntos adoptan la estructuración dantesca en cantos, como la obra de Pound, e, igual que en ésta, en ambos se escuchan varias lenguas - español, italiano, griego, latín, inglés, francés y alemán más las palabras «Snark» y «Bujum» del habla carrolliana, en «El canto...»; en «De cómo...», español, provenzal,

12.- En Blesa (1990) me he referido a este tipo de poemas anotados desde su primera edición como tumulto que nombra el silencio. 


\section{TÚA BLESA}

italiano, inglés, francés y griegn-_, el caos verbal que forja una koiné lírica. En unos y otros poemas, al igual que en la obra citada de «il miglior fabbro», la inclusión de citas es continua y diversa - por supuesto que mayoritariamente de procedencia literaria, pero también tomadas de los tebeos, de Chapters in the History of the Insane in the British Islands, o se reproduce lo que dijeron O. y E. H.- y se dan en ellos todo tipo de recurrencias: temas, motivos, personajes, frases enteras, vuelven una y otra vez. En ambos espacios líricos, como en The Cantos, la lógica del tiempo es abolida y la línea cronológica es reducida a un punto - el del propio texto-, un jardín en el que el poema, el habla, el hombre, viven huidos de la tiranía del silencio, el tiempo, la muerte.

El yo, pues, de estos poemas de Panero prolonga el discurso de Pound, se hace él, identificación que tiene su paralelo fuera del texto, pues también Panero, ya cuando escribe Teoría, ha sido encarcelado y ha iniciado la lucha con la institución psiquiátrica, la muerte en vida como paralelo biográfico.

Como muestran las páginas anteriores, la obra poética de Leopoldo María Panero ofrece toda la variedad de espejos señalados por Theodor Ziolkowski, y la riqueza de uno de ellos, el del doble, en cuanto a sus formas de expresión. Pero aquí no acaba el trabajo especular, sino que volveré a recurrir a él al considerar cierto tipo de figuras muy características de la poesía de Panero, a las que me referiré a continuación.

En muchos de los ejemplos citados anteriormente han aparecido abundantes personajes a los que les falta algún miembro, alguna de las partes integrantes de su cuerpo. Añadiré ahora algunas otras muestras, entre las que también las hay marcadas con la huella de la tradición, como es el caso que ofrece el poema "Bertrand de Born, o el oscuro enigma de la política):

Bertrand de Born ofrece en vano a los hombres en el infierno su cabeza

(El último hombre, p. 17).

La escena está tomada del canto XXVIII del Inferno, donde Dante escribe

Io vidi certo, ed ancor par ch'io 'l veggia,

un busto senza capo andar sí come

andavan li altri de la trista greggia;

e'l capo tronco tenea per le chiome, pesol con mano a guisa di lanterna; e quel mirava noi, e dicea: «Oh me!»

Di sè facea a se stesso lucerna,

ed eran due in uno e uno in due

Tal es el castigo que le corresponde en la Commedia a quien sembró la discordia entre el rey Enrique II de Inglaterra y su hijo Enrique («dividir sé, no reunir/y no conozco al hombre» son las últimas palabras del poema) y el pasaje hubo de interesar particularmente a Panero, pues a la figura fragmentada del provenzal hay que unir la rebelión del hijo contra la autoridad del padre y ese ser "due in uno e uno in due», coincidente con otras expresiones de sus poemas, a las que me he referido anteriormente.

Esta imagen decapitada de Bertrán de Born es posterior a otra muy semejante, vinculada a los relatos que oyó en su niñez el poeta, a la que se alude en el epígrafe de la parte séptima de Narciso: 


\section{EL LABERINTO DE LOS ESPEJOS}

Mi madre me contó de niño que, allá por el tiempo de esa remota leyenda que llaman guerra de España, a alguien le seccionó un obús la cabeza y siguió andando. (p. 85).

La proeza, a su vez, evoca otra ligada a L. M. ${ }^{\text {a }}$ Panero. En su mini-antología titulada «Última poesía no-española» (1979b), selecciona textos de Antonio Martínez Sarrión, Pere Gimferrer, Ana María Moix, Guillermo Carnero, Félix de Azúa, Francisco Ferrer Lerín, Antonio Colinas, Eduardo Haro, Juan Luis Panero y Fnrique Murillo, esto es, poemas de sus contemporáneos, junto a un «Romance anónimo» y un soneto de Gabriel Bocángel. Panero lo explica oscuramente en la introducción: «Incluyo un poema de Bocángel, que pertenece a mi generación» (1979b, p. 111b). La sorpresa la disipa en parte el asunto del soneto, que Bocángel dedica «A un soldado de quien se refiere que, matándole en un hecho de armas, se quedó en pie después de muerto», prodigio que Panero ya conocía de labios de Felicidad Blanc.

Estas pérdidas de partes del cuerpo están presentes en los libros de Panero desde su primera publicación. En el poema «Blancanieves...», al que me he referido antes, sobresalen sin duda, de entre la destrucción general, unos «rostros que caen sin peso sobre la hierba», en lugar de perderse en la lejanía, algo muy semejante a «Caído el rostro» de otro de los textos citados. En otro, aparecía «un pez sin ojos» y en otro se escuchaba decir a TupacAmaru «Busco aún mis ojos en la Mano», lo que en un torturado pudiera no ser particulamente curioso, pero sí que ha de serlo el que se trate de «la Mano/del hombre sin cabeza». De los numerosísimos ejemplos que podrían agregarse, recogeré ahora unos pocos: «ah Rosacruz, hermano, [...] tu cabeza cae y rueda entre los hombres/cae y rueda entre los hombres, cae/y rueda» ("La tumba de Christian Rosenkreutz», El que no ve, p. 7), «Perdí mi cabeza entre dos piedras» ([XVI], Dióscuros, p. 27), «Y su ca-/beza cae por sí sola y rueda/[...]. Como caen/dentro de mi alma, de roca en roca/los hombres que conocí, y todos los/rasgos y gestos se confunden en/un montón de ropa sucia, casca-/da informe de/piernas, brazos, ojos, ojos/cayendo de roca en roca» ("De cómo Ezra Pound...", I, El kiltimo hombre, p. 68), «Igual la lluvia deshace mi figura/y mi rostro, semejante al de Aquél, cae/herido por la piedra» y "Busco aún mis ojos en el armario» (respectivamente, de «Figuras de la Pasión del Señor» y «Cuerpo», Contra España..., pp. 24 y 39), etc. En suma, se podría decir que el cuerpo fragmentado constituye una auténtica imagen obsesiva. El siguiente poema de Narciso presenta algún otro ejemplo, además de referencias a varios otros de los asuntos aquí tratados:

\section{EL CIRCO}

Dos atletas saltan de un lado a otro de mi alma lanzando gritos y bromeando acerca de la vida: y no sé sus nombres. Y en mi alma vacía escucho siempre cómo se balancean los trapecios. Dos atletas saltan de un lado a otro de mi alma contentos de que esté tan vacía.

$$
\text { Y oigo }
$$

oigo en el espacio sin sonidos

una y otra vez el chirriar de los trapecios

una y otra vez.

Una mujer sin rostro canta de pie sobre mi alma,

una mujer sin rostro sobre mi alma en el suelo, 


\section{TÚA BLESA}

mi alma, mi alma: y repito esa palabra

no sé si como un niño llamando a su madre a la luz, en confusos sonidos y con llantos, o bien simplemente para hacer ver que no tiene sentido.

Mi alma. Mi alma

es como tierra dura que pisotean sin verla

caballos y carrozas y pies, y seres

que no cxisten y dc cuyos ojos

mana mi sangre hoy, ayer, mañana. Seres

sin cabeza cantarán sobre mi tumba

una canción incomprensible. Y se

repartirán los huesos de mi alma.

Mi alma. Mi

hermano muerto fuma un cigarrillo junto a mí.

La dualidad, desde el mismo inicio del poema, se manifiesta de múltiples maneras: en el léxico (dos, una y otra vez, repito esa palabra); en la organización sintáctica (los atletas saltan lanzando gritos y bromeando; repito esa palabra no sé si como... o bien..., en confusos sonidos y con llantos; etc.); mediante repeticiones de secuencias (Dos atletas saltan etc., se lee en dos ocasiones; oigo/oigo; una y otra vez aparece dos veces; una mujer sin rostro etc., otras dos; mi alma, mi alma, Mi alma. Mi alma y mi alma./Mi alma, etc.). En todos los niveles de la voz se nombra la disolución de la unidad, la quiebra del yo. De ahí, que el alma esté vacia y, aunque luego se cosifica, en lo que se transforma es en tierra dura, esto es, yerma, vacía de vida, que pisotean, por cierto, sin verla, tierra que resulta ser enseguida la que cubre al yo poético, ya después de muerto, en su tumba. Escribir «dos atletas», Narciso o W. Wilson es enunciar un reino de desolación, el poema que se abre con la dualidad interiorizada (los dos atletas están dentro del alma) y se cierra con el sujeto, muerto, junto a su proyección («Mi alma. Mi/hermano muerto fuma un cigarrillo junto a mí.»), el doble aniquilador, la conciencia de la muerte que el tiempo acerca, que disuelve y niega. La última presencia del poema hace pensar en un dato biográfico. Leopoldo Panero y Felicidad Blanc tuvieron después de Juan Luis, y antes que el poeta del que tratan estas páginas, otro hijo, al que se le puso el nombre de Leopoldo Quirino y que sólo vivió unos días. Cuando nazca el nuevo hijo llevará el nombre del cadáver. Si William Wilson encontró a su doble - «un ange de mort» (Rank, 1965 , p. 112) - en el colegio, Leopoldo María Panero lo tenía presente en la vida familiar esperando su nacimiento (vid. Blanc, 1977, p. 157).

Junto a la exhibición de dobles y, en su final, la muerte, destaca en el poema la continua carencia de alguna de las partes constitutivas de lo que se nombra en los versos. La falta, además, no es la de algo banal o de poca importancia, sino esencial, y se da no sólo en las figuras humanas, sino en todo tipo de entidades: de los atletas se ignoran sus nombres, los trapecios son oídos en el espacio sin sonidos, por dos veces sobre el alma canta una mujer sin rostro, se dice «mi alma», pero puede que sea para hacer ver que no tiene sentido, el alma es pisoteada por «caballos y carrozas y pies, y seres/que no existen», los seres, a continuación, son sin cabeza y la canción resulta incomprensible. Pero no el poema, que es en definitiva el mismo todo-en-ruinas que se construía ya en «Blancanieves...», la visión apocalíptica que tiñe gran parte de la escritura de Panero.

En el documento tan revelador sobre las relaciones del poeta con su familia que es El desencanto, hay un momento en que Felicidad Blanc conversa con Leopoldo María y 


\section{EL LABERINTO DE LOS ESPEJOS}

Michi, el hijo menor. La madre evoca algunos de los juegos infantiles de sus hijos: un teatro y un periódico. De éste comenta el poeta que «era un juego que teníamos Michi y yo que le llamábamos los Arongosines y que, no sé, era un mundo totalmente esquizofrénico compuesto de animales». Entre estos animales, dice, "había un perro de trapo que era el autor que más escribía libros, que se llamaba Prinlala. Escribía libros sobre su viaje a la luna, etc.», a lo que añade Michi: «escribía recetas de cocina y escribía libros médicos, que yo tengo dos ejemplares, que eran todo enfermedades inventadas, pero que realmente no eran tan inventadas, porque era todo: la pérdida de la inteligencia, la pérdida de la vista, la pérdida de..., eran todo pérdidas» (Chávarri, 1976, pp.76-78). De esta manera, «El circo» y muchos otros de los poemas de Panero son, podría decirse, una prolongación del juego infantil: pérdidas, desmembración del cuerpo, ausencia de nombre, presencia del doble. Por cierto, que la duplicación, la división, es el rasgo característico de la esquizofrenia, como esquizofrénico veía el poeta el mundo de la escritura de su niñez.

Esta poesía hace desfilar, pues, un buen número de seres marcados por la falta de alguna de las partes del cuerpo y resultaría bastante insuficiente decir de ellas que son imágenes oníricas o de un habla delirante. Podría tenerse en cuenta el tratamiento psicoanalítico clásico, tal como lo presenta Freud al referirse a este tipo de fragmentaciones del cuerpo, que serían causantes de un sentimiento siniestro, como sucede con el doble ${ }^{13}$. En «Lo siniestro», comentando el cuento de Hoffmann «El hombre de la arena», Freud escribe que

la experiencia psicoanalítica nos recuerda que herirse los ojos o perder la vista es un motivo de terrible angustia infantil. [...] El estudio de los sueños, de las fantasías y de los mitos nos enseña, además, que el temor por la pérdida de los ojos, el miedo a quedar ciego, es un sustituto frecuente de la angustia de castración. (1979, p. 21).

Pero no es únicamente la perdida de los ojos lo que puede encarnar la fantasía, sino - como Freud mismo advierte- la de otras partes del cuerpo:

Los miembros separados, una cabeza cortada, una mano desprendida del brazo $[\ldots]$, pies que danzan solos $[\ldots]$ : son cosas que tienen algo sumamente siniestro, especialmente si, como en el último ejemplo mencionado, conservan actividad independiente. Ya sabemos que este carácter siniestro se debe a su relación con el complejo de castración. (p. 29).

Indudablemente, poner en relación a estas figuras con el complejo de castración aporta algo más de sentido que la simple catalogación como imágenes oníricas. Pero no

13.- A pesar de su idéntico carácter siniestro, no tiene éste un mismo, origen en los dos casos. Según Freud, si el doble, la omnipotencia de las ideas, la realización mágica de los deseos o el retorno de los muertos son siniestros en cuanto que son convicciones primitivas en las que ya no se cree, maneras de pensar que han sido superadas, «muy otro es lo siniestro que emana de los complejos infantiles reprimidos, del complejo de castración, de las fantasías intrauterinas, etc.» $(1979$, p. 32). Ahora bien, esta distinción se aplica a la experiencia siniestra en la realidad, en la vida, y, sin embargo, Freud advierte que «lo siniestro en la ficción -en la fantasía, en la obra literariamerece en efecto un examen separado. [...] El contraste entre lo reprimido y lo superado no puede aplicarse, sin profundas modificaciones, a lo siniestro de la obra poética, pues el dominio de la fantasía presupone que su contenido sea dispensado de la prueba de realidad» (ibid.). 


\section{TÚA BLESA}

es el único modo posible de explicación dentro de la teoría psicoanalítica, y ahora me referiré a otro camino que nos conducirá de nuevo a los espejos.

Jacques Lacan - autor, por cierto, muy presente en el discurso de L. M. ${ }^{\text {a Panero- }}$ ha explicado en uno de sus estudios fundamentales, "Le stade du miroir comme formateur de la fonction du Je», la existencia de un período en el proceso de formación - que se inicia a los seis meses de edad--, en el cual el niño no identifica la unidad de los seres, tanto de las personas que ve, como de sí mismo, sino que vive en un mundo en el que existen como seres autónomos manos, brazos, pies, cabezas o troncos. El niño mismo y los demás son, en este momento, fragmentos dispersos y no un todo unido. De esta etapa primera se pasa al estadio del espejo, que debe comprenderse como «une identification au sens plein que l'analyse donne à ce terme: à savoir la transformation produite chez le sujet, quand il assume une image» (1966, p. 95). Más adelante escribe:

le stade du miroir est un drame dont la poussée interne se précipite de l'insuffisance à l'anticipation -et qui pour le sujet, pris au leurre de l'identification spatiale, machine les fantasmes qui se succèdent d'une image morcelée du corps à une forme que nous appellerons orthopédique d'une identité aliénante, qui va marquer de sa structure rigide tout son développement mental. Ainsi la rupture du cercle de l'Innenwelt à l'Umwelt engendre-t-elle la quadrature inépuisable des récolements du moi. (p. 97).

Durante el estadio del espejo, pues, este cuerpo fragmentado se reconstruye, al tiempo que se construye el yo, pero puede no desaparecer, pues

- Ce corps morcelé [...] se montre régulièrement dans les rêves, quand la motion de l'analyse touche à un certain niveau de désintegration agressive de l'individu. Il apparaît alors sous la forme de membres disjoints et de ces organes figurés en exoscopie (ibid.).

La irrupción fantasmagórica de Bertrán de Born, etc., en la poesía de Panero - y en cualquier otro discurso, poético o no-, puede ser explicada, pues, como reminiscencia de la fantasía del cuerpo fragmentado que, durante el estadio del espejo, no ha encontrado su recomposición y no ha de estar ligada, por tanto, necesariamente al complejo de castración.

Por otra parte, la interpretación de Freud antes recogida ha sido discutida, por ejemplo, por Hélène Cixous, quien propone que

La crainte pour les yeux, si elle est en rapport de substitution avec la peur de la castration, l'est tout aussi puissamment avec la peur de la folie [...]. Autrement dit, l'《incertitude intellectuelle» ne peut être rejetée comme purement intellectuelle, et la peur de la castration ne s'inscrit pas que dans le corps «réel». Elle est tout aussi intense en ce que concerne le corps symbolique, les facultés mentales. (1974, pp. 101-102).

Explicación plena de sugerencias para la lectura de la obra de Panero, en la que la locura ocupa un lugar de honor.

El mismo Lacan, en su artículo «La familia», refiriéndose al estadio del espejo, escribe que se trata

de una estructura arcaica del mundo humano, cuyos profundos vestigios han sido revelados por el análisis del inconsciente: fantasías de desmembramiento, de dis- 


\section{EL LABERINTO DE LOS ESPEJOS}

locación del cuerpo, de las que las fantasías de castración son sólo una imagen valorizada por un complejo particular; la imagen doble, cuyas objetivaciones fantásticas que se manifiestan en diversos momentos de la vida por diversas causas revelan al psiquiatra el hecho de que evoluciona con el crecimiento del sujeto; por último, el simbolismo antropomorfico y orgánico de los objetos. (1977, p. 80).

Palabras que importan especialmente en cuanto que incluyen la referencia al doble directamente relacionado con el estadio del espejo, y en cuanto que expresan claramente cómo hay más fantasías de cuerpo fragmentado que las de la castración; de manera que, ante figuras desmenbradas como las de la poesía de Panero, debería hablarse de fantasías no reconstruidas durante el estadio del espejo antes que de complejo de castración, que requeriría una exploración del conflicto edípico, pero que exigiría otro espacio que el que aquí he pretendido dedicar a la presencia de los espejos en la obra de Panero.

Ha quedado algo, sin embargo, que creo que merece un último comentario y es la referencia, antes anotada, a Bocángel. En un artículo dedicado a la poesía de Pere Gimferrer - a propósito del cual Panero ya había escrito: «mi generación se llama Pedro Gimferrer: fue él quien la construyó como lo que las generaciones son, un grupo teórico./ $\mathrm{Y}$ Pedro Gimferrer creó nuestra ideología, y fue el verdadero autor de los novísimos y, por qué no decirlo, de mí» (1979b, p. 111a)-, sentenciaba L. M. ${ }^{a}$ Panero:

creo que Gimferrer y yo somos la única poesía válida en este país. (1989, p. 105).

$Y$ en ese mismo artículo añade:

Pere Gimferrer y yo somos los dos gigantes de la poesía española actual, tal como ocurrió en otro tiempo con Quevedo y Góngora. No creo que haya ningún inconveniente en equiparar a Gimferrer con Góngora, y ello sin ningún menoscabo para los dos [...]. Por lo que se refiere a mi persona, podría equipararme, no siendo Quevedo de mi predilección, con su contemporáneo don Gabriel de Bocángel y Unzueta, que escribió versos tan magníficos como «bebe la sed en vaso que no bebe» y que fue discípulo de la belleza. (ibid.)

Si en «Última poesía no-española», trabajo al que antes me he referido, escribía Panero que Bocángel era de su misma generación, lo que explicaba que se incluyese un poema suyo en la muestra antológica, y si se tiene en cuenta el asunto del soneto cuyos primeros versos proclaman "Tu obstinado cadáver nos advierte/que hay vida muerta, pero no vencida» $y$, por otra parte, que en la selección no hay ningún poema de L. M. ${ }^{\mathrm{a}}$ Panero entre los de sus contemporáneos, siendo que es uno de los dos "gigantes de la poesía española actual», cabe pensar si no es que Bocángel, más que ser de la misma generación de Panero, es él mismo, su propio eco, la imagen encontrada en el espejo, en donde se refleja su poema: la voz de uno y otro discípulo de la belleza.

\section{REFERENCIAS}

Baltrušaitis, Jurgis (1988): El espejo, Madrid, Miraguano-Polifemo.

Blanc, Felicidad (1977): Espejo de sombras, Barcelona, Argos-Vergara.

Blesa, Túa (1990): «El silencio y el tumulto», Cuadernos de Investigación Filológica, XVI, pp. 89-107.

Campbell, Federico (1971): Infame turba, Barcelona, Lumen. 


\section{TÚA BLESA}

Castellet, Josć María (1970): Nueve novísimos poetas españoles, Barcclona, Barral.

Cixous, Hélène (1974): Prénoms de personne, París, Seuil.

Chávarri, Jaime (1976): El desencanto, Madrid, Elías Querejeta.

Dällenbach, Lucien (1972): Le livre et ses miroirs dans l'oeuvre romanesque de Michel Butor, París, Archives des lettres modernes, n.으 135.

(1977): Le récit spéculaire. Essai sur la mise en abyme, París, Seuil.

Durand, Gilbert (1981): Las estructuras antropológicas de lo imaginario, Madrid, Taurus.

Eco, Umberto (1988): “De los espejos», De los espejos y otros ensayos, Barcelona, Lumen, pp. 11-41.

Freud, Sigmund (1979): Lo siniestro, (junto con E. T. A. Hoffmann, El hombre de la arena), Barcelona, José J. de Olañeta, pp. 9-35.

Gimferrer, Pedro (1968): «Nota a la edición» en Panero, L. M.a (1968), pp. 21-22.

Lacan, Jacques (1966): Écrits, París, Seuil.

-__ (1977): La familia, Buenos Aires, Homo Sapiens.

_-_ (1990): El seminario. 1, Los escritos técnicos de Freud, Buenos Aires, Paidós.

Panero, Juan Luis (1988): «Precisión y pasión: La poesía de J. L. P.», entrevista por Fernando Valls, Insula, 494, enero, pp. 10-11.

Panero, Leopoldo María (1968): Por el camino de Swann, Málaga, Librería Anticuaria El Guadalhorce.

(1970): Así se fundó Carnaby Street, Barcelona, Llibres de Sinera.

(1973): Teoría, Barcelona, Lumen.

(1976): En lugar del hijo, Barcelona, Tusquets.

(1979a): Matemática demente, de Lewis Carroll, trad. y pról. de L. M. ${ }^{a}$ P., Barcelona, Tusquets.

(1979b): «Última poesía no-española», Poesía, 4, pp. 110-115.

-_- (1979c): Narciso en el acorde último de las flautas, Madrid, Visor.

- (1980a): Last river together, Madrid, Ayuso.

- - (1980b): El que no ve, Madrid, La banda de Moebius.

___ (1982a): La caza del Snark, de Lewis Carroll, trad. de L. M. ${ }^{a}$ P., Madrid, Ediciones libertarias.

(1982b): Dióscuros, Madrid, Ayuso.

(1984): El último hombre, Madrid, Ediciones libertarias.

(1987a): Poemas del manicomio de Mondragón, Madrid, Hiperión.

___ (1987b): Peter Pan, de James Matthew Barrie, trad. de L. M. ${ }^{a}$ P., Madrid, Ediciones libertarias.

_-_ (1989): «La poesía de Pere Gimferrer», $A B C, 4$ de marzo, «Gente y aparte», p. 105.

-_- (1990): Contra España y otros poemas no de amor, Madrid, Ediciones libertarias.

Paraíso, Isabel (1987): «Yo, el Otro», El teatro de Miguel de Unamuno, San Sebastián, Universidad de Deusto, pp. 153-188.

Poe, Edgar Allan (1970): Cuentos, trad. Julio Cortázar, Madrid, Alianza Editorial, 2 vols.

Rank, Otto (1965): Don Juan et le double. Études psychoanalytiques, París, Payot. 


\section{EL LABERINTO DE LOS ESPEJOS}

Rogers, Robert (1970): A Psychoanalytic Study of the Double in literature, Detroit, Wayne State University.

Stoljar, Margaret (1990): «Mirror and self in symbolist and post-symbolist poetry», The Modern Language Review, 85, 2, pp. 362-372.

Thompson, Stith (1966): Motif-Index of folk-literature, Bloomington, Indiana University Press.

Vinge Louise (1967): The Narcissus Theme in Western European Literature up to the Early 19th Century, Lund, Gleerups.

Ziolkowski, Theodore (1980): Imágenes desencantadas (Una iconología literaria), Madrid, Taurus. 